\title{
Citizenship and the Russian Nation during World War I: A Comment
}

\author{
S. A. Smith
}

Historians of late imperial Russia have been categorical in asserting that Russian peasants lacked any form of national identity. Scholars as diverse as Orlando Figes, Geoffrey Hosking, John Keep, Bruce Lincoln, Richard Pipes, Robert Service, Ronald Suny, and Allan Wildman have agreed that Russian peasants were too rooted in Gemeinschaft, too particularistic in their social identities, to be capable of identifying with the polity and territory of Russia. 'John Keep expresses the consensus concisely when he writes:

\begin{abstract}
At the beginning of the twentieth century the Russian people lagged behind many others in the tsarist realm (Poles, Finns, even Balts and Ukrainians) in the development of a modern national consciousness. The social elite identified with the multinational empire; in the terminology of the day their thinking was rossiiskii rather than russkii. Ordinary folk either opted for a social class orientation or else had none at all, in that their horizons were limited to the local community. This helps to explain why Russia was defeated in World War One, why the Bolsheviks with their utopian internationalist creed won mass support in 1917 and why the Whites failed to worst the Reds in the ensuing civil war. ${ }^{2}$
\end{abstract}

As this suggests, much explanatory weight has been allowed to rest on the assertion that peasants were, in the words of Richard Pipes, "virtual stranger[s] to the sentiment of patriotism." 3 Yet such categorical certainty is puzzling, given the fact that almost no empirical research has been done to date on how peasants imagined their relationship to the polity. ${ }^{4}$ The im-

1. Orlando Figes, A People's Tragedy: The Russian Revolution, 1891-1924 (London, 1996), 75; W. Bruce Lincoln, Passage through Armageddon: The Russians in War and Revolution, 1914-1918 (New York, 1986), 45-46; Richard Pipes, The Russian Revolution (New York, 1990), 203; Robert Service, A History of Twentieth-Century Russia (London, 1997), 10; Ronald Grigor Suny, The Soviet Experiment: Russia, the USSR and the Successor States (Oxford, 1998), 32; Allan Wildman, The End of Russian Imperial Army (Princeton, 1980), 1:76-77.

2. John Keep, The Last of the Empires (Oxford, 1996), 284.

3. Pipes, Russian Revolution, 203.

4. As Josh Sanborn points out, the claim that peasants lacked any sense of nationhood almost always comes from intellectuals, who fail to recognize any sense of nation hood other than their own. Yet if we accept that renditions of the nation are always plural, we can begin to investigate peasant notions without prejudice. In her account of peasants in Sierra de Puebla in Mexico, Florencia Mallon argues that "few nineteenth-century social groups, whether in Latin America or elsewhere" could be defined as possessing national identity if the nation is understood as "an already defined, integrated community with territory, language and accepted set of historical traditions." She suggests that such a version of the nation is that of the victors who seek to suppress the contests over citizenship and liberty that go on in the attempt to expand and make real the universal promises of nationalism and democracy. She shows how, beginning with the 1858-61 civil war and continuing through the French intervention, peasant guerrillas forged an alternative vision of the Mexican nation in which property rights were tempered by a commitment to solidarity and social justice while the status of citizen was tied to honorable actions rather than to birth, social class, or education. Florencia E. Mallon, Peasant and Nation: The Making of Postcolonial Mexico and Peru (Berkeley, 1995), 3, 9.

Slavic Review 59, no. 2 (Summer 2000) 
portance of the two articles by Josh Sanborn and Scott Seregny lies in the fact that they open up this apparently settled question in extremely fruitful ways. Both examine the relationship of peasants to citizenship during World War I and both challenge the dominant view that peasants remained isolated and particularistic. Josh Sanborn's wide-ranging and challenging examination of the mobilization of the male population for war in 1914 concludes that "country dwellers turned to central state institutions with complaints, constantly referred to the need to protect the 'interests of state' in their denunciations of their shirking neighbors, articulated an idea of civic equality, and appealed to a historical, territorialized community as the legitimizing political force in the country." Scott Seregny's meticulous analysis of the zemstvo-run program of adult education concludes that while peasants were not yet citizens, they could "reach out and engage the broader national community during moments of profound crisis like war or revolution."

Not least of the reasons why historians have been content with the idea that Russian peasants lacked any sense of national identity is that this accords with the most influential present-day theoretical perspective on nationalism, namely what Anthony Smith calls the "modernist paradigm." ${ }^{5}$ Writers of the caliber of Ernest Gellner, Benedict Anderson, and Eric Hobsbawm all concur that it is only possible for a political community to imagine itself as a unified subject of history, as sovereign and inherently limited, in conditions where modern communications, markets, and bureaucratic institutions exist, where the state extends its reach deep into the population through taxation and conscription, and, above all, where schooling and "print capitalism" are developed. ${ }^{6}$ This perspective has not commanded universal assent. Smith himself, while conceding that national identity is indeed a modern phenomenon, has nevertheless insisted on the relevance of older forms of ethnicity and political consciousness to nation building, particularly in those "old, continuous nations," such as Russia, to quote Hugh Seton-Watson. ${ }^{7}$ Indeed no less a figure than Hobsbawm, who otherwise insists that the "basic characteristic of the modern nation and everything connected with it is its modernity," admits that "in many parts of the world, states and national movements could mobilize certain variants of feelings of collective belonging which already existed and which could operate . . potentially on the macro-political scale." And he specifically cites Russia as his example, drawing on the seminal work of Michael Cherniavsky, while claiming rather doubtfully that the conception of "Holy Russia" lacked any association with language or ethnicity. ${ }^{9}$

5. Anthony D. Smith, Nationalism and Modernism (London, 1998).

6. Emest Gellner, Nations and Nationalism (Oxford, 1983); Benedict Anderson, Imagined Communities: Reflections on the Origin and Spread of Nationalism (London, 1983); E. J. Hobsbawm, Nations and Nationalism since 1780: Programme, Myth, Reality (Cambridge, Eng., 1990).

7. Hugh Seton-Watson, Nations and States (London, 1977), 6-13. For a vigorous defense of the premodern "nation," see Adrian Hastings, The Construction of Nationhood: Ethnicity, Religion and Nationalism (Cambridge, Eng., 1997).

8. Hobsbawm, Nations and Nationalism, 14, 46, 47.

9. Ibid., 50-51. 
Although it would be perverse to deny that the identities of Russian peasants were predominantly local in character, long-standing cultural idioms did exist that allowed Russians to think about the relationship between ethnic identity and the state. These did not allow for the imagination of nationhood in the modern sense-the ethnically defined people as the legitimating ground of the state-not least because the state in question was dynastic and multiethnic in character, but they do qualify as a form of what might be termed "protonational identity," in that they provided means whereby an ethnically defined people could imagine its relationship to the polity. ${ }^{10}$ There are signs of a distinctive ethnic identity as far back as the Tale of Igor's Campaign (c. 1200), and in ensuing centuries, this came to be articulated both negatively - in terms of "others" against whom russkie defined themselves (pagans, Catholics, Muslims, Lithuanians, Poles, Germans, Jews) - and positively." Probably the most profound positive marker of Russian ethnic identity was adherence to the eastern branch of Christianity. As Aleksandr Pushkin, among countless others, observed in his Remarks on Russian History in the Eighteenth Century, "Greek Orthodoxy, alone of anything else, gives us our particular national character." ${ }^{2}$ Second, ethnic identity was bound up with attachments to the territory of the empire that went beyond one's native place (rodina), attachments forged through legends linking particular places, such as wells, springs, burial mounds, or stones, to critical moments in the history of the motherland or to inspiring acts of heroism. Third, ethnic identity was bound up with a mythicized version of Russia's history. Historical songs and tales preserved the memory of St. Vladimir, of Ivan IV's triumphant campaign against the Tatars at Kazan', or of Peter the Great's victory at Poltava among the peasantry. Finally, ethnic identity was bound up with language and recognition of the distinctiveness of certain cultural practices and institutions, such as the commune. These idioms allowed the Russian people to imagine themselves as a community with its own history, territory, and particular beliefs and practices and were capable of becoming politicized in times of war or foreign invasion. Of course, this was not national identity in the proper sense, since the key way in which a link was forged between the imagined community of russkie and the polity was

10. Geoffrey Hosking recognizes the existence of "proto-national awareness" and discusses it in an illuminating fashion, but he, too, insists on a radical disjunction between this and modern national identity. Moreover, he emphasizes the dichotomy between two kinds of Russianness: russkii, which was connected with the people, the language, and preimperial principalities, and rossiiskii, which was associated with the territory, the multinational empire, the European great power. To my mind, the relationship between these two terms was at times closer than Hosking suggests-since rossiiskii could serve as a way of politicizing russkii. Geoffrey Hosking, Russia: People and Empire, 1552-1917 (London, 1997), 210, xix.

11. G. P. Fedotov, The Russian Religious Mind, vol. 1, Kievan Christianity: The Tenth to the Thirteenth Centuries (1946; reprint, Cambridge, Mass., 1966), 316; M. Cherniavsky, "Russia," in O. Ranum, ed., National Consciousness, History and Political Culture in Early-Modern Europe (Baltimore, 1975), 118-43.

12. A. S. Pushkin, "Zametki po russkoi istorii XVIII veka," in Polnoe sobranie sochinenii, 16 vols. (Moscow, 1949), 11:18. 
via the symbolic figure of the tsar, the "little father," who, as God's appointed representative, embodied the unity and strength of the Russian state. Down to 1905 millions of peasants continued to believe that the tsar was not only their protector but the "defender of truth" and the "upholder of the commonweal." 13

The ways in which these different idioms of ethnic identity could be mobilized for political purposes was particularly apparent in times of national crisis, such as the "fatherland war" of 1812, which spawned the last great cycle of folklore and historical songs, or the war against Poland of $1831 .{ }^{14}$ Already in the early nineteenth century, new representations of politicized ethnicity - particularly of Russia at war-began to circulate via commercial media such as woodcuts, fairground attractions, and peep shows. ${ }^{15}$ Many peep-show owners (raeshniki), for example, were former soldiers with a keen interest in broadcasting the triumphs of Russia's army and her famous generals. ${ }^{16}$ The Russo-Turkish war of $1877-78$ powerfully revealed peasants' concern for the fate of their motherland. Peddlers toured villages, selling scarves with pictures of the "leaders and heroes of the Serbian uprising in Bosnia and Herzegovina, who fought for the Christian faith and liberation of the fatherland from the barbarians." Woodcuts, showing "The Marvellous Dinner of General Skobelev under Hostile Fire," "The Storming of Kars," or "The Taking of Plevna," were widely sold. It should be noted, however, that although the peasants among whom Aleksandr Engelgardt lived, knew that Russia was fighting the Suleiman, they could not recognize the Russian flag: "No, it's the Turkish one. You see, there's an eagle drawn on it, and there'd be a cross on the Russian one." 17 The growth of a commercial press from the 1870s stimulated a gradual transformation of protonational identity into something more akin to modern national identity. Journals such as Rodina promoted new renditions of national identity which, in contrast to the doctrine of Official Nationality, centered not so much on loyalty to the tsar as on the geographical and ethnic variety of the empire and on Russia's cultural achievements. ${ }^{18}$ Through the journal Golos, A. A. Kraevskii, pioneer in commercial publishing, became a standard-bearer for Russia's civilizing mission in

13. L. T. Senchakova, Prigovory i nakazy rossiiskogo krest'ianstva, 1905-1907 gg. (Moscow, 1994), 208.

14. A. V. Buganov, Russkaia istoriia v pamiati krest'ian XIX veka i natsional'noe samosoznanie (Moscow, 1992), 148-72. My view of national identity in Russia has been significantly shaped by this pathbreaking work, which is the first empirical study of what I call "protonational identity," but which the author calls "national consciousness." He concludes that there was a "relatively high level of national consciousness" among Russian peasants by the nineteenth century.

15. Catriona Kelly, Petrushka: The Russian Carnival Puppet Theatre (Cambridge, Eng., 1990), 27-28.

16. A. F. Nekrylova, Russkie narodnye gorodskie prazdniki, uveseleniia i zrelishcha (Leningrad, 1988), 116-25.

17. Aleksandr Nikolaevich Engelgardt, Letters from the Country, 1872-1887, ed. and trans. Cathy A. Frierson (New York, 1993), 135.

18. Jeffrey Brooks, When Russia Learned to Read: Literacy and Popular Literatures, 18611917 (Princeton, 1985), chap. 6. 
Asia. ${ }^{19}$ The appearance of the postcard in 1872 helped to popularize new visual images of the empire/nation, as did the proliferation of cultural and scientific organizations, museums, and exhibitions. These new renditions of national identity were more inclusive, more populist, and more politically sophisticated than those of Official Nationality or of protonational identity. They were nevertheless still tied to empire, the conquest of exotic regions being seen as emblematic of Russia's standing alongside the major powers of Europe. Of course, up to the early twentieth century, peasant identifications with the polity continued to be articulated mainly in terms of loyalty to the tsar and to Orthodoxy, but these elements were gradually becoming superannuated and other elements in the repertoire of protonational identity, such as the emotional attachment to a now enlarged conception of Russia's territory, greater knowledge about her history, pride in her cultural achievements, especially those of the nineteenth century, or truisms about the virtues (and vices) of the Russian people, were being reworked into something more recognizably like modern national identity. ${ }^{20}$

Neither Sanborn nor Seregny attends to the issue of continuity between national identity and earlier forms of politicized ethnicity, since both implicitly subscribe to the modernist paradigm of nation building, but I think that it is only by examining national identity in a longer historical perspective that one can appreciate the distinctive ways in which the national "we" was constructed, and the broader social and political implications of its differing constructions. Since Russia was one of the "old, continuous nations," the task of constructing national identity was easier than in many countries, since elements from the repertoire of protonational identity could be appropriated and put to new uses; at the same time, that repertoire set parameters within which the construction of national identity took place. Sanborn perceptively suggests that the socioeconomic processes associated with modernization, such as the erosion of local and regional autonomy brought about by market penetration, improved communications, the increase in geographical and social mobility, the growth of schooling, universal conscription, and the spread of cultural homogeneity, provided a build-up of "energy" that allowed "nationness" to happen. I would simply add that the gradual transformation in protonationalist identity which took place following the expansion of "print capitalism" was another factor which provided some of that "energy."

Both writers agree that the events of 1905 unleashed the energy that had been building up, setting in motion the growth of national identity on a mass scale. The revolution offered the promise of a nation united, as reform-minded elements of the middle classes and gentry joined forces with

19. Alfred J. Rieber, "Russian Imperialism: Popular, Emblematic, Ambiguous," Russian Review 53 (July 1994): 333.

20. This is how I read the evidence put forward in the innovative piece by Yulia Mikhailova, "Images of Enemy and Self: Russian 'Popular Prints' of the Russo-Japanese War," Acta Slavica Japonica 16 (1998): 30-53. She shows how "traditional" elements, such as Ivan Krylov's fables, were mobilized in the discourse of national defense. 
the labor movement in an "all-nation struggle" to end the war with Japan and achieve a constitution. In the countryside the most intense wave of agrarian disorders since the Pugachev rebellion of $1773-75$ broke out, at the forefront of which was the very particular peasant concern with the land. ${ }^{21}$ Yet this did not preclude peasants from engaging with the nation. The dominant political idiom in both town and countryside was that of "citizenship" (grazhdanstvo) and "liberty" (svoboda), and it was not uncommon for peasants to represent themselves as "free Russian citizens." ${ }^{22}$ More than ever before, they read newspapers, sought information about national politics, composed petitions, and voted in Duma elections. ${ }^{23}$ Senchakova's analysis of 661 petitions shows the extent to which peasants vested hopes in the Duma, seeing in it not only a body capable of redistributing land but a democratic organ answerable to the wishes of the people. Moreover, as a result of the brutality with which the peasant movement was suppressed, millions jettisoned their age-old faith in the tsar as a protector. Sanborn shows that in the armed forces, too, the revolution galvanized a movement in which service to the nation became detached from service to the tsar. ${ }^{24}$ Following Russia's defeat at the hands of the Japanese, the ascendancy of young reformers in the military establishment led to reservists - two-thirds of whom were now literate-receiving a "stridently national military training," which placed the interests of the nation on a par with those of the tsar, thereby creating a situation in which, when war broke out in 1914, peasants were mobilized within the framework of the nation.

Sanborn and Seregny demonstrate that non-Russian ethnic groups were capable of being mobilized within - and of identifying with - the rossiiskii state. After 1905, this was increasingly construed in national rather than dynastic or polyethnic terms. Yet the contradictions between nation and empire seem to me to run deeper than the two authors suggest. The policy of Russification, for instance, pursued inconsistently since the reign of Alexander III, had sought to draw non-Russian peoples into the empire by inculcating the language, religion, culture, and history of Russia, but it had backfired, spurring non-Russian peoples to begin to en-

21. Abraham Ascher, The Revolution of 1905, vol. 1, Russia in Disarray (Stanford, 1988), 267.

22. Senchakova, Prigovory, 109, 111-24.

23. Abraham Ascher, The Revolution of 1905, vol. 2, Authority Restored (Stanford, 1992), 5 .

24. Even among the Cossacks, detachment from the ideal of service to the person of the tsar was perceptible, if only embryonically. Shane O'Rourke, "The Don Cossacks during the 1905 Revolution: The Revolt of Ust-Medvedevskaia Stanitsa," Russian Review 57 (October 1998): 583-98. After 1905 advocates of military reform contrasted the "patriotism, enthusiasm and self-sacrifice of Japanese private soldiers" with their Russian counterparts and urged a militarization of the school curriculum. See William C. Fuller, CivilMilitary Conflict in Imperial Russia, 1881-1914 (Princeton, 1985), 195, 198. For a general argument that military factors were as important as economic ones in promoting national integration, see Barry R. Posen, "Nationalism, the Mass Army and Military Power," in John L. Comaroff and Paul C. Stern, eds., Perspectives on Nationalism and War, International Studies in Global Change, vol. 7 (Luxembourg, 1995), 135-85. 
tertain a solution to their problems within a separatist national rather than a Russian imperial frame. ${ }^{25}$ In this respect, too, the 1905 revolution marked a turning point, amplifying the potential for separatist nationalisms. In Armenia the socialist Dashnak movement succeeded in rallying pan-class support behind nationalist symbols, while in Latvia peasants and workers went on strike, refused to pay rents, and boycotted courts and administrative institutions run by Russians. The revolution thus intensified the contradiction between a burgeoning Russian national identity and the incipient nationalisms of the empire's non-Russian subjects (or, more precisely, of educated strata thereof), even if it did not make that contradiction unresolvable. And as my sketch of protonationalist identity was intended to suggest, the more inclusive renditions of the Russian idea that began to circulate in the last decades of the nineteenth century were implicitly imperial, rooted in a belief in the superiority of Russian culture and in the duty of the Russian people to act as "elder brother" toward the non-Russian peoples. After 1905 the meaning of empire began to change, but therein lay the rub: for if, on the one hand, the empire was increasingly seen as a multinational state rather than a polyethnic dynastic polity; on the other, rossiiskii was becoming increasingly aligned with russkii. In my view, World War I was significant less in disclosing the potential for non-Russian subjects to identify with the travails of the motherland-although that is an important finding of these two articles-than in exposing the incapacity of the rossiiskii state to serve as a framework for articulating multinational aspirations. In promoting the Russian nation as a category of practice, the tsarist state unintentionally served to delegitimize rossiiskii as an ideal with which non-Russians could identify and accelerated trends whereby they came to refocus their identities around their own national symbols. ${ }^{26}$ The war thus revealed the incapacity of the weakly integrated and underinstitutionalized tsarist state to stretch-in Benedict Anderson's neat formulation - "the short, tight skin of the nation over the gigantic body of the empire." 27

If the interplay between nation and empire, between non-Russian and Russian national aspirations, was more conflictual than Sanborn and Seregny allow, so was the relationship between national and class identities. Sanborn makes the sharp point that the nation is defined neither by social unity nor by loyalty to the government. Yet most writers on nationalism posit that a key test of the strength of the nation is its capacity to overcome class divisions, at least in moments of crisis. Tom Nairn defines nationalism as the creation of a "militant, inter-class community rendered strongly (if mythically) aware of its own separate destiny vis-à-vis the outside forces of domination." ${ }^{8}$ And Michael Mann defines a nation as "an extensive cross-class community affirming its distinct ethnic identity and history and

25. Hosking, Russia, 376, 397.

26. Mark von Hagen, "The Russian Empire," in Karen Barkey and Mark von Hagen, eds., After Empire: Multiethnic Societies and Nation-Building: The Soviet Union and the Russian, Ottoman and Habsburg Empires (Boulder, Colo., 1997), 58-72.

27. Anderson, Imagined Communities, 84.

28. T. Nairn, The Break-up of Britain (London, 1977), 340. 
claiming its own state." ${ }^{29}$ Both these definitions may go too far in implying that the nation must subsume class identities, but they remind us that the relationship between the two is potentially conflictual..$^{30}$ Again, a longer perspective on the history of the Russian "nation" reminds us of the extent to which the brief moments of achievement of a "cross-class community" were undermined by profound social conflict. Peasants, while perfectly capable of identifying with the imagined community of the Russian state, especially when it was in danger, were at the same time profoundly alienated from the vlast', the landed gentry, and the upper classes (verkhi). If peasant historical memory celebrated major victories over the enemies of Orthodoxy, it also celebrated episodes of resistance to landowners, as shown by the plethora of folksongs that lauded popular rebels, such as Ataman Ermak, Stenka Razin, and Emel'ian Pugachev. Again the 1905 revolution was crucial in revealing that the relationship between national and class identities could be both mutually constitutive and potentially antagonistic. If the revolution held out the promise of a nation united in struggle against the autocracy, it also starkly underlined the danger of a class war. Even as peasants identified with the nation by voting in Duma elections, they set about wreaking vengeance on the landowners. And if the period after 1905 saw public life increasingly constituted within a national framework, peasants were regularly reminded that they were not yet seen as qualifying for membership in the nation. The determination of the zemstvo gentry, for example, to stifle peasant aspirations for fairer representation in the institutions of local and national government, intensified their alienation from the verkhi, even as those aspirations testified to a desire for equal participation in the polity. ${ }^{31}$ In a curious paradox, therefore, burgeoning national identity served to firm up class identity.

Sanborn is well aware of the contradictory interplay of class and nation, since he follows Prasenjit Duara's injunction to think of the nation as an object of contestation rather than of loyalty. His nuanced discussion of the differentiated responses to the outbreak of war in 1914 demonstrates that there was a potential both for cross-class unity as well as for class division. Yet his argument that the "relatively new sense of the nation as the dominant framework of political practice ... grew stronger during the war" may be too one-sided. For his part, Seregny shows that the zemstvos seized on the war as an opportunity to foster peasant identification with the nation through an ambitious program of adult education and contends that an unprecedented dialogue between the so-called third element and the peasantry took place through lectures, newspaper readings, and besedy (discussions which have a parallel in the causeries organized by

29. M. Mann, The Sources of Social Power (Cambridge, Eng., 1993), 2:215.

30 . I stress that I am not arguing that national and class identities are mutually exclusive. There are plenty of historical examples where national and class identities have been mutually constitutive. In the democratic states of western Europe and the United States, for example, labor movements promoted the interests of their members largely through the political structures of the nation-state; see Carolyn M. Vogler, The Nation State: The Neglected Dimension of Class (Aldershot, 1985), xii.

31. Roberta T. Manning, "The Zemstvo and Politics, 1864-1914," in Terence Emmons and Wayne S. Vucinich, eds., The Zemstvo in Russia (Cambridge, Eng., 1982), 133-76. 
the Union des Grandes Associations contre la Propagande Ennemie in rural France).$^{32}$ In addition, he provides evidence of intense interest in the war on the part of peasants in Ufa province, a situation mirrored elsewhere. ${ }^{33}$ For example, the recently published diary of A. A. Zamaraev, an industrious peasant in a remote village in Vologda, not only reveals deep patriotism but surprising knowledge about the course of the war. Typical is an entry for July 1916:

The war has now been going on two years and no end is in sight. Our heroes, generals Brusilov, Lichitskii, and Sakharov, have taken hundreds of thousands of prisoners since May... Hero Tatarov has fallen in battle. As he fell, wounded in the heart by shrapnel, he managed to jump to his feet to cry out "Forward, Regiment!" And then he died. ${ }^{34}$

It is noticeable that Zamaraev makes not a single mention of the tsar in his many entries concerning the war. I am entirely persuaded by Seregny's argument that the war multiplied opportunities for peasants to engage with the nation, yet he too may minimize the extent to which the zemstvos served to deepen peasants' sense of exclusion from society (a point to which I shall return). Both authors, in other words, may underestimate the extent to which war caused national and class identities to pull apart. This was probably more evident in the towns than in the countryside-at least before 1917-since the war, while bringing hardship to the countryside in the form of inadequate subsidies for families left without a breadwinner, a shortage of labor, a decline in trade, rising prices, and a lack of basic consumer goods, did not bring the same degree of deprivation to peasants as to urban dwellers. In the towns, however, the upsurge of working-class economic and political discontent in 1916 suggests to me that the relationship between national and class identities was increasingly antagonistic. In his pathbreaking work on patriotic mass entertainment, Hubertus Jahn demonstrates that the nation weakened as a focus of identity for the urban lower classes, since patriotic rhetoric lost its capacity to make sense of the growing social and political crisis. At the same time, he shows that patriotism did not disappear, but instead became focused on idealized images of family and village rather than on the official symbols of nationality ${ }^{35}$

While I would place greater emphasis than Sanborn or Seregny on the ways in which the war strengthened class identity at the expense of na-

32. John Horne, "Remobilizing for 'Total War': France and Britain, 1917-18," in John Horne, ed., State, Society and Mobilization in Europe during the First World War (Cambridge, Eng., 1997), 205.

33. For more examples, see I. Odinskii, "Iz dnevnika krest'ianina," Ezhemesiachnyi zhurnal, February 1915, no. 2:130-32; S. Semenov, "Derevnia vo vremia voiny," Ezhemesiachnyi zhurnal, March 1915, no. 3:63-74. This journal carried a regular "Diary from the Countryside" throughout the war. 138-39.

34. Dnevnik Totemskogo krest'ianina A. A. Zamaraeva, 1906-22 gg. (Moscow, 1995),

35. Hubertus F. Jahn, "Patriots or Proletarians? Russian Workers and the First World War," in Reginald E. Zelnik, ed., Workers and Intelligentsia in Late Imperial Russia: Realities, Representations, Reflections (Berkeley, 1999), 330-47. 
tional identity, I think they are entirely correct to reject a historiographical consensus which assumes that class and national identities are mutually exclusive and that the strength of class identity in 1917 must signify the weakness or nonexistence of national identity. In this connection, both writers engage with the admirable article by David Moon which examines developments in late imperial Russia through the optic of France during the Third Republic. ${ }^{36}$ Among many astute points advanced, Moon makes a thought-provoking contrast between the inability of the Provisional Government to prevent the disintegration of the Russian army in the summer of 1917 and the success of the French authorities in the same year in regaining control of the army after widespread mutinies. He explains this as being a consequence of the "very weakly developed sense of national consciousness" among Russia's "peasant mutineers," compared with the "citizen-soldiers" of France. This has a certain plausibility, and I shall not reject it outright, but it is too neat a dichotomy. Was it not precisely the demand to be treated as "citizen-soldiers" that ranked foremost among the claims of rank-and-file soldiers in the February revolution? And throughout the spring of 1917 did not soldiers respond warmly to calls by the moderate socialists to defend the gains of the revolution against AustroGerman militarism? Only in the wake of the disastrous June offensive did the Russian army disintegrate, as soldiers despaired of seeing an end to the bloodshed, grew angry at the unequal burden of sacrifice, and steeled their resolve to lay hands on gentry lands. Certainly, appeals to national unity became discredited, yet even as the army broke down, and as intense class struggles spread across Russia, it is doubtful whether one can unilaterally endorse P. V. Struve's dictum of August 1918, that the revolution "was the first case in world history of the triumph of internationalism and the class idea over nationalism and the national idea." ${ }^{37}$ It is more convincing, in my view, to see the intense class struggles of 1917 as, in part, struggles to define the meaning of the nation, with Kadet visions of gosudarstvennost', nadklassounost', and the nation-under-siege in competition with revolutionary defensism and with the latter in competition with revolutionary renditions of the narod which, playing upon its double sense of "nation" and "common people," strove to define the nation as one that was based exclusively on the toiling people. ${ }^{38}$ To talk about the weakness of "national consciousness," therefore, as does Moon, captures only one side of the picture: yes, by the summer of 1917 appeals to classes to unite in defense of the nation were discredited, yet the persistence of themes of citizenship and patriotism suggests that too much explanatory weight should not be placed on this as a factor in explaining the outcome of the war. Indeed Leonard Smith's account of the French army, on which Moon relies, makes clear that the mutinies were brought to an end as much by General Pé-

36. David Moon, "Peasants into Russian Citizens? A Comparative Perspective," Revolutionary Russia 9, no. 1 (June 1996): 43-81.

37. P. V. Struve, "Istoricheskii smysl russkoi revoliutsii i natsional'nye zadachi," Iz glubiny: Sbornik statei o nusskoi revoliutsii (1918; reprint, Moscow, 1990), 235.

38. This theme is developed in S. Smit [S. A. Smith], "Klass, natsiia i obshchestvennaia politika v russkoi revoliutsii 1917 goda," Vestnik Omskogo universiteta, 1996, no. 2:57-66. 
tain's judicious mix of repression and reform as by the internal suasion exercised on French soldiers by the ideals of citizenship. ${ }^{39}$

In thinking about the salience of national identity, it may be more fruitful to compare Russia with the belligerent states in which military defeat led to revolution. Germany is particularly interesting since, like Russia, it had embarked on nation building relatively late and its status as a nation/empire was similarly ambivalent. How did the claim to nationhood, for instance, square with Prussian dominance of the federal structure of the Kaiserreich? How did aspirations to imperial expansion square with the exigencies of national integration? The uncertainty of Germany's elites concerning whether her destiny lay in an enlarged ethnically German state (that is, one including Austria) or in a central European mixednationality state, to some degree, mirrored the uncertainties of Russia's elites with regard to the policy of Russification. ${ }^{40}$ In the light of such ambiguities, historians of Germany have differed in their assessment of the success of nation building after 1871, some insisting that Germany was a Reich ohne Nation, others that it was remarkably successful in producing a sense of unity and collective identity among its citizens. ${ }^{4 l}$ Even those most skeptical about the success of nation building, however, such as Michael Hughes, concede that when war broke out in August 1914, the "German nation experienced unprecedented unity." ${ }^{2}$ During the first two years of war, the German government, like its British and French counterparts, appears to have relied more on persuasion than on coercion. ${ }^{43}$ By July 1916, however, Germany had plunged into political crisis, as food shortages, inflation, and war weariness stoked up labor discontent, as the military refused to countenance political reform, and as the government proved unable to balance civilian and military needs or to negotiate the "tensions arising from the conflictual social morality and competing claims of sacrifice on the home front." ${ }^{44}$ The crisis was in fact overcome; and revolution did not break out until late 1918. Nevertheless the breakdown of class collaboration, the emergence of widespread alienation from the government, and the outbreak of extensive social conflict make Germany more comparable to Russia than France. However, in seeking to explain these developments, historians of Germany ascribe little determinacy to the strength of national identity as a factor. John Breuilly goes so far as to say that "the sense that Germans were members of a national community was

39. Leonard V. Smith, "Remobilizing the Citizen-Soldier through the French Army Mutinies of 1917," in Horne, ed., State, Society and Mobilization, 144-59.

40. John Breuilly, "Nation and Nationalism in Modern German History," Historical Journal 33, no. 3 (1990): 659-75.

41. Michael Hughes, Nationalism and Society: Germany, 1800-1945 (London, 1988); David Blackbourn, The Long Nineteenth Century: The Fontana History of Germany, 1780-1918 (London, 1997), 424; John Breuilly, "The National Idea in Modern German History," in Mary Fulbrook, ed., German History since 1800 (London, 1997), 569.

42. Hughes, Nationalism and Society, 14.

43. John Horne, "Introduction: Mobilizing for 'Total War,' 1914-18," in Horne, ed., State, Society and Mobilization, 5.

44. Ibid., 16. 
immeasurably strengthened by experience of war." 45 And even a historian such as Wilhelm Deist, who argues that in the offensive of March 1918 soldiers "did not fight out of national enthusiasm as in 1914" but because they were "tied into the universal principle of command and obedience," suggests that the authority structure of the army was a more important factor than the subjective morale of the men ${ }^{46}$ Comparison with Germany, then, suggests that we should be cautious about attaching too much weight to purportedly weak national identity in making sense of the events of 1917. Russia's failure to sustain the war arguably had far more to do with the inability of the economy to sustain the burdens of "total war," with the inability of existing institutions to cope with the massive task of military and civilian mobilization, and with the inflexibility of military and political leaders than it had to do with weak national identity.

Nevertheless, it is hard to avoid the conclusion that national identity played some part in influencing the outcome of the revolution, given the hegemony of class in 1917. And while I would argue that class politics can be read as a contest to determine whose version of the nation should triumph, the extent to which the political language of nation became utterly discredited in the eyes of workers, soldiers, and peasants is still striking. In other words, when all caveats have been entered, Struve still has a point. National solidarity does appear to have been weaker in Russia than in France or Germany. At this juncture, we should recall Seregny's conclusion that although the war saw peasants engaging with the nation to an unprecedented extent, this did not mean that they were "transformed into citizens." We thus come back to the central question posed by Moon: why did Russian peasants fail to become citizens? It is interesting that although Moon pays most attention to the socioeconomic processes conventionally seen as underpinning nation building, concluding that they touched rural society in Russia only lightly compared with France, in the last analysis, he comes down firmly in favor of a political explanation, pointing to the exclusion of peasants from national political life as the fundamental factor determining the weakness of national identity in Russia. We may quibble about whether national identity really was weak, but it is incontrovertible that nationalism everywhere has been bound up with the idea of citizens enjoying membership in a political community by virtue of shared nationality. Moon is thus, surely, right to suggest that the major factor impeding the development of national identity in Russia was the inability of Russian peasants to participate in the polity on an equal footing with other social groups. Again, the comparison with Germany is telling. In 1871 it might have seemed that the prospects for nation building were better in Russia than in the new German state, since it was less unitary in structure than the tsarist autocracy and faced tasks of creating a unified executive and legislature, codifying law, creating a single currency, and so forth. Yet these tasks were successfully carried out. More important, a functioning Reichs-

45. Breuilly, "National Idea," 572.

46. Wilhelm Deist, "The German Army, the Authoritarian Nation-State and Total War," in Horne, ed., State, Society and Mobilization, 170. 
tag was established which, in spite of serious imperfections from the point of view of democracy, did succeed in acquiring national legitimacy. In the elections of 1912, for example, 80 percent of males over the age of 24 cast a vote. It is true that contemporaries were struck more by the limitations of the Reichstag, by the extent to which it dramatized class and ethnic divisions, yet it can justly claim to have transformed German men into citizens. ${ }^{47}$ The contrast with Russia is obvious. After 1861 the government pledged to overcome the estate particularism of the peasantry and to integrate them gradually into citizenship, first through the zemstvos (1864) and ultimately through representative institutions of government. Some progress was made in this direction, evident in the institution of universal military service, the abolition of peasant passports, the abolition of estatespecific taxes, and the eventual institution of income tax (1916). Yet the key institutions of peasant separateness, such as distinctive systems of local administration and volost $t^{\prime}$ courts, remained in place. In practice, the poor resource base of the empire, its huge size, the ever-present danger of social disorder, meant that the state remained perforce reliant on the particularistic institutions which, in theory, it sought to eliminate. ${ }^{48}$ This is evident in regard to the putatively "all-class" zemstvos, in which estate distinctions remained rigidly institutionalized down to 1917. Seregny highlights the ongoing vitality of the zemstvos, yet overlooks the fact that they were a standing reminder to the peasants of their exclusion from full citizenship. ${ }^{49}$ If the nation is indeed a category of practice, then the zemstvos-in contrast to the army after 1905-served as a category that reproduced particularistic identities based on social estate even as they gestured toward the ideal of citizenship.

These two articles are thus greatly to be welcomed in that they open up a long overdue debate about the meaning and extent of national identity at the end of the ancien regime. Both query the widely held but poorly founded assumption that nationhood was alien to the Russian peasant, and both shed doubt on the equally widely held assumption that weak national identity was a major cause of Russia's failure in World War I and her failure to produce a stable democratic regime after the February revolution. At the same time, we should not lose sight of the fact that peasant identification with the nation, while steadily growing, was critically impeded by the government's failure to grant them rights of citizenship. Moreover, if the 1905 revolution was the defining moment that allowed "nationness" to happen it also stimulated the construction of other social identities, including new configurations of imperial identity, anti-imperial identities, and, above all, class identity, all of which were potentially in conflict with national identity. In my view, the principal consequence of the war was to exacerbate the tensions between these different sources of

47. Blackbourn, Long Nineteenth Century, 266; Breuilly, "National Idea," 570.

48. Peter Gatrell, "Poor Russia: Environment and Government in the Long-Run Economic History of Russia," in Geoffrey Hosking and Robert Service, eds., Reinterpreting Russia (London, 1999), 89-106.

49. William G. Rosenberg, "The Zemstvo in 1917 and Its Fate under Bolshevik Rule," in Emmons and Vucinich, eds., Zemstvo in Russia, 415. 
social identity. I am convinced by Sanborn's and Seregny's suggestion that the war strengthened rather than weakened national identity, but I think they underestimate the extent to which nation, empire, and class pulled in different directions from 1916. The February revolution briefly eased the tensions, but by the summer of 1917 , politics had become polarized between an imperial language of nation, used mainly by the privileged and educated strata, an anti-imperial language, used mainly by the elites of the non-Russian nationalities, and a language of class, used mainly by the subaltern classes. This was essentially a conjunctural phenomenon, and the extent to which class identity "triumphed" over national identity should not be exaggerated. When workers and soldiers briefly backed the Bolsheviks in their bid to establish soviet power, they did so because they believed it was in the interests of the people/nation and the salvation of Russia. It is arguable - although beyond the compass of this short piece to make the argument - that class identity ultimately proved ephemeral, whereas Russian national identity proved to be surprisingly robust. 